\title{
ABSTRACT \\ NITRIC OXIDE METABOLITES IN HYPOXIA, FREEZING, AND HIBERNATION OF THE WOOD FROG, RANA SYLVATICA
}

\author{
by Bethany Lin Williams
}

Nitric oxide (NO) is a gaseous free radical that in diverse organisms performs many signaling and protective functions, including: vasodilation, inhibition of apoptosis, antioxidation, and metabolic downregulation. Increased NO availability may be especially important during periods when organisms must contend with multiple stresses. We investigated stress-induced changes in $\mathrm{NO}$ metabolites, nitrite $\left(\mathrm{NO}_{2}^{-}\right)$and nitrate $\left(\mathrm{NO}_{3}{ }^{-}\right)$, in the blood plasma, heart, liver, and gracilis of the wood frog (Rana sylvatica), which endures chronic cold, freezing, hypoxia, dehydration, and extended aphagia during hibernation. We found elevated concentrations of $\mathrm{NO}_{2}{ }^{-}$and/or $\mathrm{NO}_{3}{ }^{-}$in the plasma, heart, and liver of hypoxia-exposed frogs $\left(24 \mathrm{~h}, 4^{\circ} \mathrm{C}\right)$, and in liver of frogs exposed to freezing $\left(48 \mathrm{~h},-2.5^{\circ} \mathrm{C}\right)$, suggesting that increased $\mathrm{NO}$ availability aids in surviving these stresses. During a 32-week period of simulated hibernation, $\mathrm{NO}_{2}{ }^{-}$and/or $\mathrm{NO}_{3}{ }^{-}$increased in the plasma, heart, and liver during an initial 5-week winter-conditioning regimen and generally remained elevated thereafter. In hibernation, plasma $\mathrm{NO}_{2}^{-}$was higher in frogs indigenous to Interior Alaska than in conspecifics from a temperate locale. Our results, together with published values for other species, suggest that the NO protection system is of general importance in the stress adaptation of vertebrates. 
NITRIC OXIDE METABOLITES IN HYPOXIA, FREEZING, AND HIBERNATION

OF THE WOOD FROG, RANA SYLVATICA

\author{
Thesis \\ Submitted to the \\ Faculty of Miami University \\ in partial fulfillment of \\ the requirements for the degree of \\ Master of Science \\ by \\ Bethany Lin Williams \\ Miami University \\ Oxford, Ohio \\ 2018 \\ Advisor: Jon P. Costanzo \\ Reader: Richard E. Lee Jr. \\ Reader: Kathleen A. Killian
}

(C)2018 Bethany Lin Williams 
This thesis titled

NITRIC OXIDE METABOLITES IN HYPOXIA, FREEZING, AND HIBERNATION OF THE WOOD FROG, RANA SYLVATICA

by

\author{
Bethany Lin Williams
}

has been approved for publication by

College of Arts and Science

and

Department of Biology

Dr. Jon P. Costanzo

Dr. Richard E. Lee Jr.

Dr. Kathleen A. Killian 


\section{Table of Contents}

LIST OF TABLES IV IV

LIST OF FIGURES

ACKNOWLEDGEMENTS VI

INTRODUCTION

$\begin{array}{ll}\text { MATERIALS AND METHODS } & 3\end{array}$

EXPERIMENTAL ANIMALS $\quad 3$

TISSUE SAMPLING

ASSAY OF NO METABOLITES

EXPERIMENTAL HYPOXIA EXPOSURE AND RECOVERY 4

EXPERIMENTAL FREEZING AND THAWING

NO AVAILABILITY IN HIBERNATION

$\begin{array}{ll}\text { STATISTICAL INFERENCES } & 7\end{array}$

$\begin{array}{lr}\text { RESULTS } & 7\end{array}$

HYPOXIA EXPOSURE AND RECOVERY $\quad 8$

$\begin{array}{ll}\text { FREEZING AND THAWING } & 9\end{array}$

NO AVAILABILITY IN HIBERNATION 9

EXPOSURE TO ENVIRONMENTAL NITRATE 10

$\begin{array}{ll}\text { DISCUSSION } & 10\end{array}$

$\begin{array}{ll}\text { REFERENCES } & 15\end{array}$

$\begin{array}{lr}\text { FIGURES } & 20\end{array}$

$\begin{array}{lr}\text { TABLES } & 21\end{array}$ 


\section{List of Tables}

Table 1 Concentrations of $\mathrm{NO}$ metabolites $\left(\mathrm{NO}_{2}{ }^{-}\right.$and $\left.\mathrm{NO}_{3}{ }^{-}\right)$in blood plasma and organs of Ohioan wood frogs sampled after hypoxia exposure or hypoxia exposure followed by $4 \mathrm{~h}$ of normoxia exposure (recovery)

Table 2 Concentrations of $\mathrm{NO}$ metabolites $\left(\mathrm{NO}_{2}{ }^{-}\right.$and $\left.\mathrm{NO}_{3}^{-}\right)$in blood plasma and organs of Ohioan wood frogs sampled after being subjected to a survivable freeze/thaw bout

Table 3 Concentrations of $\mathrm{NO}_{2}^{-}$in the blood plasma of some vertebrates 


\section{List of Figures}

Figure 1 Concentrations of $\mathrm{NO}$ metabolites $\left(\mathrm{NO}_{2}^{-}\right.$and $\left.\mathrm{NO}_{3}^{-}\right)$in blood plasma and organs of Alaskan wood frogs sampled shortly before entering hibernation $(\mathrm{PH})$, at the onset of hibernation (HO), at the hibernal midpoint (MH), or late in hibernation, shortly before emerging (IE); see Materials and methods for sampling details. Units are $\mu$ mol $\mathrm{l}^{-1}$ (plasma) or nmol g ${ }^{-1}$ fresh tissue (organs). Within each panel, group means ( \pm SEM, $n=4-9)$ assigned distinct letters were statistically distinguishable $(P<0.05)$ 


\section{Acknowledgements}

We thank C. do Amaral for aiding with the frog collection. She and K. Killian provided constructive comments on the manuscript. Supported in part by the National Science Foundation (Grant IOS1022788 to JPC 


\section{Introduction}

Nitric oxide (NO) is a gaseous free radical that diffuses freely across biological membranes due to its highly lipophilic nature. It is quickly oxidized to nitrite $\left(\mathrm{NO}_{2}{ }^{-}\right)$and nitrate $\left(\mathrm{NO}_{3}{ }^{-}\right)$and therefore has a very short half-life (Umbrello et al. 2013). In various organisms, NO plays a host of signaling and protective roles, such as regulation of vascular tone, metabolic regulation, inhibition of platelet adhesion, and antioxidation (Fago and Jensen 2015; Forstermann and Sessa 2012). NO typically exerts its effects either directly by binding to the iron moiety of heme proteins, or indirectly by reacting with reactive oxygen species (ROS) and, for example, Snitrosylating proteins, which alters the structure or activity of over 1,000 proteins (Benhar 2015; Fago and Jensen 2015). All eukaryotes and many prokaryotes are known to produce NO (Crane et al. 2010; González-Domenech and Muñoz-Chápuli 2010).

In animals, NO is primarily produced via the L-arginine pathway using the enzyme nitric oxide synthase (NOS). Two constitutive NOS isoforms, endothelial NOS (eNOS) and neuronal NOS (nNOS), named for where they were first discovered, occur in vertebrates other than fishes, which apparently lack eNOS. A third isoform, also found in vertebrates, is inducible NOS (iNOS), which can be stimulated in any cell (Forstermann and Sessa 2012; Olson et al. 2012). Whereas NOS is oxygen-dependent, $\mathrm{NO}$ is produced in hypoxic tissues from $\mathrm{NO}_{2}^{-}$and $\mathrm{NO}_{3}{ }^{-}$by the nitrate-nitrite-NO pathway (Lundberg et al. 2008). Diet, inhalation of atmospheric NO, and production of $\mathrm{NO}_{3}{ }^{-}$by bacteria are potential, additional sources of NO (Kleinbongard et al. 2003; Lundberg et al. 2008). Uptake across permeable body surfaces occurs in some species, although the generality and significance of this mode of acquisition is unknown (Jensen 2009; Rouse et al. 1999). NO's production and accrual is balanced by its metabolism and the loss of $\mathrm{NO}_{2}{ }^{-}$and $\mathrm{NO}_{3}{ }^{-}$ in urine and feces (Kelm 1999).

High availability of NO can be protective during acute or chronic stresses. For example, hypoxia-tolerant ectotherms, including red-eared sliders (Trachemys scripta elegans) and crucian carp (Carassius carassius) respond to decreasing tissue oxygen tension by increasing the concentrations of NO metabolites in one or more body compartments, apparently through recruitment from internal reservoirs (Jensen et al. 2014; Sandvik et al. 2012) and/or de novo production via an upregulated expression of NOS (McNeill and Perry 2006). Elevated NO reportedly protects hypoxic tissues by inhibiting apoptosis, limiting the formation of ROS, and suppressing metabolism (Fago and Jensen 2015). Some organisms maintain relatively high 
constitutive levels of NO metabolites to prepare for impending stress. For example, African lungfish (Protopterus aethiopicus) upregulate NOS expression in heart, lung, and kidney during aestivation. Additionally, in the mouse-eared cress (Arabidopsis thaliana), cold-acclimation leads to an increase in NO that is correlated with enhanced freeze tolerance (Puyabert and Baudouin 2014).

Considering its myriad signaling and protective functions, we posit that NO plays an especially important role during life-history periods in which organisms must contend with diverse physiological stresses. This supposition could be investigated by measuring changes in NO availability in a species that has evolved profound tolerances to homeostatic perturbations arising from exposure to variable and extreme conditions within its natural habitat. In this regard, the winter physiology of the wood frog (Rana sylvatica) presents an ideal study system. The most northerly distributed of North American amphibians, $R$. sylvatica hibernates for up to 8 months in a shallow, terrestrial form, where it readily endures chronic cold, dehydration, hypoxia, corporeal freezing, and extended aphagia (Costanzo et al. 2015; Larson et al. 2014). In the laboratory, winter-acclimatized frogs tolerate the loss of up to $40 \%$ of their body water, the freezing of up to $65-70 \%$ of their body water, and exposure to hypoxia for several days (Costanzo et al. 1993; Holden and Storey 1997). Whether or not NO contributes to their survival of these stresses is as yet unknown.

Our primary aim in this study was to infer a protective role of NO in hibernating $R$. sylvatica by examining their potential to mobilize NO metabolites in response to hypoxia exposure and freezing exposure, two formidable winter stresses. We also tested the hypothesis that hibernating frogs maintain high constitutive levels of NO metabolites in anticipation of the various stresses imposed by the harsh winter environment. Experimenting with specimens collected from subarctic and cool-temperate populations provided insights into the possibility that NO levels vary among conspecifics adapted to different climatic regions. Finally, we addressed the question of whether exposure to $\mathrm{NO}_{3}{ }^{-}$in the environment influences endogenous $\mathrm{NO}$ levels in hibernating frogs. 


\section{Materials and methods}

\section{Experimental animals}

Male frogs were collected in Adams County, Ohio, USA $\left(38.8^{\circ} \mathrm{N}, 83.5^{\circ} \mathrm{W}\right)$, when they emerged from hibernacula between late January and early February 2017. These frogs were transported to our laboratory and housed at $4{ }^{\circ} \mathrm{C}$ in darkened boxes containing damp moss for 2 weeks to allow them to resume dormancy. They were used in experiments within 3 weeks.

Frogs of both sexes were collected in early August 2016 in Fairbanks, North Star Borough, Alaska, USA $\left(64.8^{\circ} \mathrm{N}, 147.7^{\circ} \mathrm{W}\right)$, transported under refrigeration to our laboratory, and put in individual plastic containers on dampened, unbleached paper towels. We sampled several frogs immediately, but others were subjected to a winter-acclimatization regimen and then held in simulated hibernation (details provided below).

Frogs were collected under permits from the Ohio Division of Wildlife and the Alaskan Department of Fish and Game. Rearing, euthanasia, and experimental protocols were approved by the Institutional Animal Care and Use Committee (IACUC) of Miami University.

\section{Tissue sampling}

We euthanized frogs by double-pithing them and measured their snout-ischium length and body mass after draining any bladder fluid via a glass cannula inserted into the cloaca. Blood was collected from a small cut in the aortic trunk into microcapillary tubes treated with anticoagulant (EDTA or heparin) and centrifuged $\left(2,000 \mathrm{~g}, 5 \mathrm{~min}, 4^{\circ} \mathrm{C}\right)$ to isolate the plasma, which was stored at $-80{ }^{\circ} \mathrm{C}$ until assayed for NO metabolites; for some experiments plasma was also assayed for glucose and lactate using enzymatic, colorimetric assays (G7521 and L759650, respectively, Pointe Scientific, Canton, MI, USA). Next, we quickly opened the coelom, skinned one hind limb, and severed the head at the occiput in order to collect the brain, heart, and portions of the liver and a skeletal muscle ( $m$. gracilis). These samples were rinsed in HEPES buffer (mmol 1-1: HEPES, 5.0; $\mathrm{NaCl}, 124.1 ; \mathrm{KCl}, 5.0 ; \mathrm{CaCl}_{2}, 1.8 ; \mathrm{MgCl}_{2}, 1.6$ ), blotted dry on lab tissue, placed in cryovials, immersed in liquid $\mathrm{N}_{2}$, and stored at $-80{ }^{\circ} \mathrm{C}$ before being assayed for NO metabolites. For experiments in which stress (hypoxia exposure or freezing/thawing) was expected to alter the liver's hydration state, an additional tissue sample was immediately weighed, placed in a $65^{\circ} \mathrm{C}$ oven, and reweighed after thoroughly dried; the initial water 
concentration was then determined from the mass lost upon drying. Euthanasia, dissection, and tissue sampling were carried out at $4{ }^{\circ} \mathrm{C}$.

\section{Assay of NO metabolites}

In several experiments we measured the concentrations of $\mathrm{NO}_{2}{ }^{-}$and $\mathrm{NO}_{3}{ }^{-}$, proxies for $\mathrm{NO}$, in plasma and organs. Organ samples were thawed on ice, minced with a razor blade, and homogenized in phosphate-buffered saline (PBS; mmol 1-1 ${ }^{-1} \mathrm{NaCl}, 104.5 ; \mathrm{Na}_{2} \mathrm{HPO}_{4}, 6.2 ; \mathrm{KCl}$, 2.0; $\mathrm{KH}_{2} \mathrm{PO}_{4}, 1.1$ ) in a bead tube (Bullet Blender Storm 24, Next Advance, Troy, NY, USA). Homogenates were centrifuged $\left(10,000 \mathrm{~g}, 20 \mathrm{~min}, 4^{\circ} \mathrm{C}\right)$ and the resulting supernatants were deproteinated using a $10 \mathrm{kDa}$ Nominal Molecular Weight Limit ultrafiltration device (Amicon Ultra-0.5, Millipore, Billerica, MS, USA) centrifuged at $14,000 \mathrm{~g}$ for $30 \mathrm{~min}$ at $4{ }^{\circ} \mathrm{C}$. Thawed plasma samples were also deproteinated using this method. Concentrations of $\mathrm{NO}_{2}{ }^{-}$and $\mathrm{NO}_{3}{ }^{-}$ were measured fluorometrically using a kit (780051, Cayman Chemical, Ann Arbor, MI, USA). To minimize contamination of the samples with ambient $\mathrm{NO}_{2}{ }^{-}$and $\mathrm{NO}_{3}{ }^{-}$, glassware and filters were rinsed with ultrapure water before use. PBS was prepared using ultrapure water and checked periodically for $\mathrm{NO}_{2}{ }^{-}$and $\mathrm{NO}_{3}{ }^{-}$contamination.

\section{Experimental hypoxia exposure and recovery}

Ohioan frogs were transferred from their holding boxes to cylindrical, acrylic metabolic chambers (Qubit Systems no. G115, Kingston, ON, Canada) that were kept within the same refrigerated room. Frogs were confined to a bag of nylon netting to restrict their movement and placed on damp paper towels. Metabolic chambers (volume: mean $\pm \mathrm{SEM}=184 \pm 2 \mathrm{ml} ; n=8$ ), outfitted with a Luer valve near each end, were flushed with $\mathrm{N}_{2}$ gas for $\sim 15$ min before both valves were closed, following the protocol of Rosendale et al. (2014). Frogs were kept in these chambers for $24 \mathrm{~h}$, at $4{ }^{\circ} \mathrm{C}$, in darkness. A gas sample was drawn from one valve using a 60-ml Hamilton syringe and measured for oxygen concentration using an oxygen analyzer (model S3A/I; AEI Technologies, Pittsburgh, PA, USA). Frogs were sampled either immediately $(n=8$; hypoxia-exposed) or $4 \mathrm{~h}$ after breathing humid, normoxic air ( $n=8$; hypoxia recovery), which was continuously flushed through the chambers with the aid of a small aquarium pump. Results from both groups were compared to values determined for reference frogs $(n=8)$ sampled directly from their holding boxes. 
Experimental freezing and thawing

Ohioan frogs $(n=8)$ were placed in small, plastic deli cups on moist paper towels and a layer of damp moss and covered by a small, inverted cup to restrict their movement. Frogs were cooled from $4{ }^{\circ} \mathrm{C}$ to $-2.5^{\circ} \mathrm{C}$ over a period of $48 \mathrm{~h}$ and then held at $-2.5^{\circ} \mathrm{C}$ for $48 \mathrm{~h}$ inside a programmable incubator (Percival, model I-35X, Boone, IA, USA); such slow freezing facilitates cryoprotective responses and mimics natural freeze/thaw episodes (Costanzo and Lee 2013). Ice chips were added to the moss to initiate freezing of the moss, and ultimately the frog, through inoculative freezing (Layne 1991). After freezing, frogs were transferred to a cold room $\left(4{ }^{\circ} \mathrm{C}\right)$ to permit thawing and sampled $12 \mathrm{~h}$ later. Reference frogs $(n=8)$ from the hypoxiaexposure experiment (described above) also served as (unfrozen) reference frogs in this experiment.

NO availability in hibernation

We tested the hypothesis that Alaskan frogs maintain high constitutive levels of NO to protect against the various stresses they incur during winter. Pre-hibernal frogs ( $\mathrm{PH} ; n=9)$ were sampled on 19 August, promptly upon their arrival in our laboratory. Additional frogs were sampled at the beginning, midpoint, or end of hibernation, which was simulated using the Percival programmable incubator to provide naturalistic variations in temperature and photoperiod. Environmental conditions during this 38-week period of simulated hibernation were based on NOAA meteorological records, field observations of hibernacula (Kirton 1974; Larson et al. 2014), and protocols used in previous investigations (Costanzo et al. 2013; Costanzo et al. 2015).

We used a 5-week regimen of winter acclimatization to prepare the frogs for long-term dormancy. Initially, chamber temperature varied daily from 17.0 to $8.0^{\circ} \mathrm{C}$ and photophase was $16.5 \mathrm{~h}$, but weekly decrements were made and, during week 5 , temperature varied from 13.0 to $2.5^{\circ} \mathrm{C}$ and photophase was $13.3 \mathrm{~h}$. Hibernal-Onset frogs (HO; $\left.n=9\right)$ were sampled on 20 September, immediately after this regimen ended. During the following week, chamber temperature oscillated daily from 5.0 to $0.5^{\circ} \mathrm{C}$ and the photophase was $12.5 \mathrm{~h}$. Thereafter, frogs were exposed to (static) $0.5{ }^{\circ} \mathrm{C}$ in darkness, conditions commonly occurring within hibernacula beneath snowpack (Kirton 1974; Larson et al. 2014). We sampled Mid-Hibernal frogs (MH; $n=$ 9) after 11 weeks, on 14 December. The remaining frogs were held at $0.5{ }^{\circ} \mathrm{C}$ for an additional 19 weeks before being subjected to a 2-week regimen of rising temperature and lengthening 
photophase (week 1: 0.5 to $5.0^{\circ} \mathrm{C}, 15 \mathrm{~h}$ photophase; week $2: 2.0$ to $10.0{ }^{\circ} \mathrm{C}, 16 \mathrm{~h}$ photophase); Imminent-Emergence frogs (IE; $n=5$ ) were sampled at the end of this regimen, on 9 May.

Frogs in simulated hibernation were housed individually within polyethylene containers (floor area, $56.7 \mathrm{~cm}^{2}$ ) that contained a shelter (inverted, opaque cup with an opening in its side) and two layers of unbleached paper towel wetted with spring water. Initially, $2.5 \mathrm{ml}$ water was used; however, because the water potential of natural hibernacula is relatively low (Costanzo and Lee 2005), we reduced the volume to $1.0 \mathrm{ml}$ beginning in week 3 of the simulation. We placed inside each container 3-6 small crickets, which had been topically treated with vitamin supplement (ReptoCal, Tetrafauna, Blacksburg, VA, USA), thrice weekly. Most frogs ceased feeding by the end of week 3 , so thereafter food was withheld.

The aforementioned caging was replaced weekly with clean materials during the 5-week regimen of winter acclimatization. We then modified the caging to provide for the needs of dormant frogs. The container's shelter was exchanged for a smaller cup, which, inverted over the frog, limited its movement; beneath the cup, the frogs adopted the posture exhibited by frogs hibernating in nature (Kirton 1974; Larson et al. 2014). Florist's moss, moistened with spring water, was placed over and around the inverted cup to maintain humidity and exclude ambient light. Frogs remained undisturbed within these hibernation cages for the remainder of the simulation. However, we removed the moss from the cup's (translucent) top at the start of the final two weeks so that frogs could perceive the photic cues intended to stimulate their arousal.

\section{Exposure to environmental nitrate}

To determine whether exposure to environmental $\mathrm{NO}_{3}{ }^{-}$can impact endogenous levels of $\mathrm{NO}$ metabolites, we assayed the tissues of frogs bathed in nitrate-enriched water. We used Alaskan frogs that had been subjected to a winter-acclimatization regimen and subsequently held at 0.5 ${ }^{\circ} \mathrm{C}$ in simulated hibernation (as described above) for $\sim 34$ weeks. Frogs were removed from their hibernation cages and placed individually in a clean polyethylene container that was covered with a perforated lid. Containers received a $1.4 \mathrm{mmol} \mathrm{l}^{-1}$ sodium nitrate solution $(n=6)$ or, in the case of reference frogs $(n=7)$, bottled spring water (Ice Mountain, Nestle Waters North America, Stamford, CT, USA). To achieve maximal exposure to the bath, each container held $\sim 100 \mathrm{ml}$ of nitrate solution or water, sufficient to submerge the frog without covering its head. 
Frogs were held in their containers for $48 \mathrm{~h}$, at $4{ }^{\circ} \mathrm{C}$, in darkness, and then immediately sampled for bladder fluid, euthanized, wrapped in foil, and plunged into liquid $\mathrm{N}_{2}$. Carcasses, bladder fluid, and bath samples were briefly stored at $-80{ }^{\circ} \mathrm{C}$ before being assayed for $\mathrm{NO}_{2}{ }^{-}$and $\mathrm{NO}_{3}{ }^{-}$. Carcasses were thawed, minced finely with a razor blade, and processed with a rotor/stator-type tissue homogenizer (Tissue-Tearor, BioSpec Products Inc., Bartlesville, OK, USA); the aqueous fraction was isolated and deproteinized as described for organ homogenates. Assay of $\mathrm{NO}_{2}{ }^{-}$and $\mathrm{NO}_{3}{ }^{-}$in carcass extracts, and in the thawed bath samples, was carried out using the aforementioned fluorometric procedure. We determined levels of $\mathrm{NO}_{\mathrm{x}}\left(\mathrm{NO}_{2}{ }^{-}+\mathrm{NO}_{3}^{-}\right)$in the samples of bladder fluid because their small size precluded separate determination of both metabolites.

\section{Statistical inferences}

Summary statistics are presented as mean \pm SEM unless otherwise indicated. Comparisons between two groups were made using the Student's $t$-test. However, in one case, in which data did not meet assumptions of homoscedasticity, Welch's Test for Unequal Variance was used. Comparisons among three groups were made using an ANOVA followed by a Student-NewmanKeul's Multiple Comparison test. In some cases, it was necessary to log- or square root transform data to meet assumptions of normality and homoscedasticity. Significance was accepted at $P<0.05$.

\section{Results}

Overall, concentrations of $\mathrm{NO}$ metabolites varied among tissues. $\mathrm{NO}_{2}{ }^{-}$levels tended to be highest in plasma and lowest in liver, whereas those in heart and muscle were usually similar and intermediate to concentrations in plasma and liver. $\mathrm{NO}_{3}{ }^{-}$concentrations were typically several orders of magnitude higher than $\mathrm{NO}_{2}{ }^{-}$and tended to be highest in heart and (like $\mathrm{NO}_{2}^{-}$) lowest in liver. It was necessary to pool the brains from three individuals to obtain a detectable signal; as such, we determined metabolites in this organ only for frogs in one experiment. Generally, concentrations of $\mathrm{NO}_{2}{ }^{-}$and $\mathrm{NO}_{3}{ }^{-}$in brain tissue were comparable to those determined for heart and muscle. 
Hypoxia exposure and recovery

Chamber air sampled at the end of the 24-h trial contained little oxygen (mean $\pm \mathrm{SD}=2.5 \pm$ $1.3 \%$ oxygen; $n=16$ ), confirming that the frogs had been continuously exposed to hypoxia. Most of the hypoxia-exposed frogs were largely unresponsive to tactile stimulation and lacked the hindlimb retraction reflex (albeit had autonomically contracting hearts); in contrast, hypoxiarecovery frogs ventilated their lungs, exhibited normal body posture, and generally demonstrated the righting reflex.

The concentration of lactate in plasma varied $(P<0.001)$ among groups, being higher in the hypoxia-exposed frogs $\left(31.2 \pm 4.1 \mathrm{mmol} \mathrm{l}^{-1}\right)$ and hypoxia-recovery frogs $\left(35.5 \pm 3.0 \mathrm{mmol} \mathrm{l}^{-1}\right)$ than in reference frogs $\left(1.7 \pm 0.3 \mathrm{mmol}^{-1}\right)$. Levels of glucose also varied $(P<0.001)$ among groups, being higher in hypoxia-exposed frogs $\left(16.0 \pm 2.5 \mathrm{mmol} \mathrm{l}^{-1}\right)$ and hypoxia-recovery frogs $\left(11.0 \pm 0.7 \mathrm{mmol} \mathrm{l}^{-1}\right)$ than in reference frogs $\left(1.9 \pm 0.2 \mathrm{mmol}^{-1}\right)$. Expectedly, water concentration of the liver (determined as $\mathrm{g}$ water $\mathrm{g}^{-1}$ dry tissue) varied with treatment (hypoxiaexposed: $3.2 \pm 0.1$; hypoxia-recovery: $3.1 \pm 0.1$; reference: $2.8 \pm 0.1 ; P=0.013$ ); thus, it was necessary to express hepatic concentrations of NO metabolites relative to the mass of dry tissue.

Relative to the values for reference frogs, concentrations of NO metabolites in plasma, heart, and liver (but not muscle) tended to be higher in hypoxia-exposed frogs (Table 1). Marked variation occurred in the plasma of the latter, where concentrations of $\mathrm{NO}_{2}{ }^{-}$and $\mathrm{NO}_{3}{ }^{-}$were from 2.4- to 4.1-fold higher than in reference frogs. Similarly, the concentration of $\mathrm{NO}_{2}^{-}$in heart was 2.8-fold higher in hypoxia-exposed frogs than in reference frogs. The level of $\mathrm{NO}_{3}{ }^{-}$in heart showed a similar, but non-significant, trend. Concentrations of NO metabolites in muscle of reference and hypoxia-exposed frogs were indistinguishable. In liver, $\mathrm{NO}_{3}{ }^{-}$(but not $\mathrm{NO}_{2}{ }^{-}$) was 4.1-fold higher in hypoxia-exposed frogs than in reference frogs.

In hypoxia-recovery frogs, concentrations of $\mathrm{NO}_{2}{ }^{-}$and/or $\mathrm{NO}_{3}{ }^{-}$were higher in heart and liver, but not in muscle or plasma, as compared to those of reference frogs (Table 1). Concentrations of $\mathrm{NO}_{2}{ }^{-}$in heart were 3.1-fold higher in hypoxia-recovery frogs as compared to reference frogs; nominally (albeit not significantly) higher levels of $\mathrm{NO}_{3}{ }^{-}$were also seen. Levels of both metabolites in liver were from 1.8- to 3.4-fold higher in the hypoxia-recovery frogs than in reference frogs. 


\section{Freezing and thawing}

Frozen/thawed frogs exhibited the hindlimb-retraction reflex and normal posture, indicating that they had survived freezing and were in the early stages of recovery. Concentrations of lactate in their plasma $\left(18.6 \pm 5.0 \mathrm{mmol} \mathrm{l}^{-1}\right)$ were $\sim 11$-fold higher $(P<0.001)$ relative to those of reference frogs $\left(1.7 \pm 0.8 \mathrm{mmol} \mathrm{l}^{-1}\right)$. Glycemic levels in frozen/thawed frogs $\left(37.2 \pm 6.0 \mathrm{mmol} \mathrm{l}^{-}\right.$

$\left.{ }^{1}\right)$ were $\sim 20$-fold higher $(P<0.001)$ than those of reference frogs $\left(1.9 \pm 0.2 \mathrm{mmol} \mathrm{l}^{-1}\right)$. Water concentrations in the livers of frozen/thawed frogs $\left(4.5 \pm 0.1 \mathrm{~g}\right.$ water $\mathrm{g}^{-1}$ dry tissue) were considerably higher $(P<0.001)$ than those of reference frogs $\left(2.8 \pm 0.1 \mathrm{~g}\right.$ water $\mathrm{g}^{-1}$ dry tissue $)$; thus, we reported hepatic metabolite concentrations relative to the mass of dry (rather than fresh) tissue.

Freezing/thawing differentially affected concentrations of NO metabolites in the tissues we examined (Table 2). Levels of $\mathrm{NO}_{2}^{-}$in plasma were $58.4 \%$ lower in frozen/thawed frogs than in reference frogs, whereas corresponding levels of $\mathrm{NO}_{3}{ }^{-}$were nearly significantly higher $(P=$ 0.079). In liver, concentrations of both NO metabolites were higher (from 1.6- to $~ 3$-fold) in frozen/thawed frogs relative to those in reference frogs, but neither $\mathrm{NO}_{2}{ }^{-}$nor $\mathrm{NO}_{3}{ }^{-}$varied in heart or muscle.

\section{NO availability in hibernation}

Generally, tissues of hibernating frogs (i.e., HO, MH, and IE groups) maintained higher concentrations of $\mathrm{NO}_{2}{ }^{-}$and $\mathrm{NO}_{3}{ }^{-}$as compared to those of $\mathrm{PH}$ frogs (Fig. 1). For example, marked variation occurred in plasma concentrations of $\mathrm{NO}_{2}^{-}(P<0.001)$ and $\mathrm{NO}_{3}^{-}(P<0.001)$, these levels being higher in the hibernators by up to 14.7-fold and 3.5-fold, respectively. Strong differences were seen among the concentrations of $\mathrm{NO}_{2}^{-}(P<0.001)$ and $\mathrm{NO}_{3}{ }^{-}(P<0.001)$ in heart, with HO frogs having the highest concentrations of all groups. Skeletal muscle also varied in concentrations of $\mathrm{NO}_{2}{ }^{-}(P<0.001)$ and $\mathrm{NO}_{3}{ }^{-}(P<0.001)$, but the pattern in this organ- $\mathrm{NO}_{2}{ }^{-}$ peaking later in hibernation and $\mathrm{NO}_{3}{ }^{-}$being scarce in $\mathrm{HO}$ frogs - was unlike that seen in plasma and heart (Fig. 1). In liver, concentrations of $\mathrm{NO}_{2}{ }^{-}$were remarkably uniform among groups $(P=$ $0.611)$, whereas levels of $\mathrm{NO}_{3}{ }^{-}$varied haphazardly $(P<0.001)$.

Concentrations of $\mathrm{NO}_{2}{ }^{-}$in (pooled) brains of $\mathrm{PH}, \mathrm{HO}$, and $\mathrm{MH}$ frogs were $0.5 \pm 0.2,2.2 \pm$ 0.7 , and $1.2 \pm 0.4 \mathrm{nmol} \mathrm{g}^{-1}$ fresh tissue, respectively, and did not vary $(P=0.107 ; n=3)$. Corresponding concentrations of $\mathrm{NO}_{3}{ }^{-}$were 1,502 $\pm 442,296 \pm 176$, and 2,508 $\pm 1,206 \mathrm{nmol} \mathrm{g}^{-1}$ 
fresh tissue, and also did not vary $(P=0.054)$. We did not assay NO metabolites in the brains of IE frogs.

\section{Exposure to environmental nitrate}

Frogs bathed for $48 \mathrm{~h}$ in nitrate solution or spring water appeared healthy and exhibited typical behaviors and posture. Samples of nitrate solution and spring water collected at trial's end had concentrations of $\mathrm{NO}_{3}{ }^{-}$that strongly differed $\left(1,304 \pm 29\right.$ versus $\left.30 \pm 6 \mu \mathrm{mol} \mathrm{l}^{-1} ; P<0.001\right)$. In contrast, there were no differences in concentrations of $\mathrm{NO}_{2}^{-}$(nitrate solution: $0.1 \pm 0.03 \mu \mathrm{mol} \mathrm{l}^{-}$

1; spring water: $\left.0.1 \pm 0.02 \mu \mathrm{mol} \mathrm{l}{ }^{-1} ; P=0.428\right)$. Carcass levels of $\mathrm{NO}_{2}{ }^{-}$were indistinguishable $(P$ $=0.269)$ between the frogs exposed to nitrate solution $\left(5.4 \pm 0.5 \mathrm{nmol} \mathrm{g}{ }^{-1}\right.$ fresh tissue $)$ and the reference frogs $\left(7.6 \pm 1.7 \mathrm{nmol} \mathrm{g}^{-1}\right.$ fresh tissue), as were corresponding levels of $\mathrm{NO}_{3}{ }^{-}(202 \pm 70$ versus $163 \pm 40 \mathrm{nmol} \mathrm{g}^{-1}$ fresh tissue, respectively; $P=0.620$ ). We could collect only a small amount of bladder fluid from each frog and, unfortunately, the samples from two individuals were too small to assay. The concentration of $\mathrm{NO}_{\mathrm{x}}$ in bladder fluid from frogs exposed to nitrate solution, $2,749 \pm 1,121 \mu \mathrm{mol} 1^{-1}(n=4)$, was nearly double that of the reference frogs $(1,475 \pm$ $\left.660 \mu \mathrm{mol} \mathrm{l}^{-1}, n=7\right)$, but this difference was not significant $(P=0.142)$.

\section{Discussion}

The goal of this study was to deduce a protective role of NO by examining the responses of NO metabolites to acute stresses associated with winter and the dynamics of NO during hibernation. We found a strong mobilization of NO metabolites in response to hypoxia in multiple body compartments, and an increase in liver in response to freezing. After a five-week winteracclimatization regimen, NO metabolites were generally higher, and these increases were typically sustained throughout winter. Our results provide evidence for a putative protective role of NO against these acute and chronic stresses.

Hypoxia tolerance is well developed in certain ectotherms, such as turtles that survive without oxygen for months during winter dormancy, and fishes that remain active in oxygendepleted waters. Most amphibians cannot survive prolonged hypoxia (Bickler and Buck 2007; Jackson and Ultsch 2010), although $R$. sylvatica exhibits a modest tolerance (Holden and Storey 1997) that probably helps them survive within terrestrial hibernation burrows and endure ischemic hypoxia during freezing. 
When subjected to experimental hypoxia, our $R$. sylvatica accrued glucose and lactate, indicating that they relied on anaerobic metabolism. In these frogs, NO availability increased in plasma, liver, and heart, similar to the response of profoundly hypoxia-tolerant species $T$. scripta and $C$. carassius (Jensen et al. 2014; Sandvik et al. 2012). The especially pronounced increase (2.8-fold) in NO metabolites in heart, and their maintenance even in normoxic recovery, is consistent with that observed in hearts of T. scripta and C. carassius and indicative of NO's important role in cardioprotection (Jensen et al. 2014; López-Barneo et al. 2010; Sandvik et al. 2012).

The potential protective benefits of high NO availability in hypoxic and hypoxia-recovering tissues include antioxidation, limiting the formation of ROS, inhibition of apoptosis, metabolic suppression by competing with oxygen for Complex IV of the electron transport chain, and induction of heat shock protein 70 production (Fago and Jensen 2015; Hogg and Kalyanaraman 1999; Xu et al. 1997). NO apparently protects against hypoxia even in relatively hypoxiaintolerant species. For example, administering $\mathrm{NO}_{2}^{-}$decreased necrosis and apoptosis in hepatocytes of mice and limited cardiac infarct in mice and rats (Duranski et al. 2005; Webb et al. 2004). The apparently robust NO mobilization system of $R$. sylvatica presumably contributes to its relatively higher tolerance to hypoxia as compared to other amphibians.

$R$. sylvatica tolerates the freezing of as much as two-thirds of its body water and thus can endure terrestrial hibernation in cold climates (Costanzo and Lee 2013). Freeze tolerance in this species and others depends on the accrual of cryoprotective agents and a host of molecular adaptations that limit injury to cells and tissues (Storey and Storey 2017). NO reportedly increases survival of freezing of some plants (Puyabert and Baudouin 2014), but its potential to limit cryoinjury in animals has not been researched.

Our frogs exhibited the usual responses to freezing and thawing, including accrual of glucose and lactate, indicating that they were adequately challenged by our experimental protocol. We expected to observe increased levels of NO metabolites in frozen/thawed frogs, which was the case with liver, in which NO plays several roles in regulating glucose metabolism (Jobgen et al. 2006). However, levels in skeletal muscle and heart were no higher than those of unfrozen reference frogs. The reason these organs apparently lacked a mobilization response is unknown. Conceivably, their constitutive levels of NO were adequate under the relatively modest freezing exposure we used. Alternatively, they may have accrued smaller amounts of NO metabolites that 
were cleared or metabolized during thawing; sampling tissues from fully-frozen frogs would help address this question. Unexpectedly, the concentration of $\mathrm{NO}_{2}^{-}$(but not $\mathrm{NO}_{3}^{-}$) in plasma was reduced, rather than increased, in frozen/thawed frogs. This drop could be due to a transfer of vascular $\mathrm{NO}_{2}{ }^{-}$to intracellular spaces for use in synthesizing $\mathrm{NO}$ via the nitrate-nitrite-pathway as occurs with hypoxia exposure in C. carassius and C. auratus (Hansen and Jensen 2010; Sandvik et al. 2012). This pathway, which is enhanced in hypoxic tissues (Lundberg et al. 2008), is active in amphibians during both normoxic and hypoxic conditions (Forgan et al. 2018).

In freezing $R$. sylvatica, NO likely protects against ischemic hypoxia, which develops when the heart stops beating and blood flow ceases (Costanzo and Lee 2013; Storey and Storey, 2017), by effecting antioxidation, inhibition of apoptosis, and metabolic suppression (Fago and Jensen 2015). It may provide other benefits, as well. Through its vasodilatory effect, NO potentially enhances delivery of the cryoprotectant glucose to peripheral tissues and could also increase its uptake by skeletal muscle (Jobgen et al. 2006; Umbrello et al. 2013). By inhibiting glycogenesis and glycolysis in hepatocytes (Jobgen et al. 2006), NO would supplement the effect of downregulated fructose-2,6-bisphosphate (Illanes and Storey 1993) in preserving the cryoprotectant pool amassed during freezing. Future research should explore the potential for NO to protect against freezing-induced perturbations such as iono-osmotic stress, destabilization of macromolecules and membranes, and molecular crowding.

In the weeks before entering hibernation, $R$. sylvatica undergoes a host of molecular, biochemical, and physiological adjustments that permit its survival during the ensuing winter. We investigated the dynamics of NO availability during hibernation in frogs adapted to survive the exceptionally long and harsh winters of Interior Alaska. Generally, levels of NO metabolites increased during winter acclimatization, perhaps in response to decreases in photophase, temperature, and/or moisture, and remained elevated through late hibernation, suggesting that high availability of NO contributes to winter survival. Increased NO production during acclimatization potentially could reflect an upregulation of NOS, as occurs in the estivating lungfish and cold-acclimated toad, Bufo (Rhinella) arenarum (Filogonio et al. 2017; González Nicolini et al. 1998), and, presumably, the increased availability of its substrate arginine (Wu and Morris 1998), a likely consequence of heightened activity of the ornithine-urea cycle in these frogs (Costanzo et al. 2015). The synthesis of both NO and urea utilizes arginine and produces citrulline, which was higher in winter-acclimated frogs and can be recycled to arginine through 
the citrulline/NO pathway to support NO production (Wu and Morris 1998). Although NO metabolite levels in the blood and sampled organs generally were higher in hibernation, concentrations of $\mathrm{NO}_{2}{ }^{-}$in liver were unexpectedly low and extremely static. Reduced levels of NO in this organ may be necessary to permit glycogen deposition and conversion of accrued lactate to glucose during post-freeze recovery (Jobgen et al. 2006).

Maintaining high constitutive levels of NO in some organs during hibernation would not only augment the amount mobilized during hypoxia exposure or freezing, but likely could protect them from other homeostatic disturbances. Dehydration is a potential stressor of hibernating $R$. sylvatica due to their preference for relatively dry hibernacula (Costanzo et al. 2015). $\mathrm{NO}_{\mathrm{x}}$ increases in the dehydrating rat, presumably because it plays a regulatory role in fluid homeostasis (Mornagui et al. 2006). NO can contribute to hypometabolism (Fago and Jensen 2015) which, in aphagic frogs, would extend the availability of their endogenous energy stores.

NO is mainly produced enzymatically, but additional amounts can be acquired through the diet, produced by bacteria (Lundberg et al. 2008), or, in the form of $\mathrm{NO}_{2}{ }^{-}$and $\mathrm{NO}_{3}{ }^{-}$, taken up across body surfaces (Jensen 2009; Rouse et al. 1999). Amphibians, with their large expanse of permeable skin, would seem capable of supplementing endogenous NO production with environmental sources. Despite the potential toxicity of environmental $\mathrm{NO}_{2}{ }^{-}$and $\mathrm{NO}_{3}{ }^{-}$, and the anthropogenic problems of high $\mathrm{NO}_{3}{ }^{-}$, in the environment (Rouse et al. 1999), there are few measurements of endogenous levels of NO metabolites in amphibians and virtually no studies of the effects of environmental NO sources on those internal levels. However, transcutaneous uptake can be presumed from studies showing that environmental $\mathrm{NO}_{3}{ }^{-}$can cause developmental aberrations in frogs (Guillette and Edwards 2005). In our R. sylvatica, exposure to environmental $\mathrm{NO}_{3}{ }^{-}$had no effect on the whole-body levels of $\mathrm{NO}$ metabolites, indicating that they regulated endogenous levels by metabolizing or eliminating any excess. Nominally (albeit not significantly) higher concentrations of $\mathrm{NO}_{\mathrm{x}}$ in their bladder fluid imply that excess $\mathrm{NO}$ metabolites were voided through renal excretion. There are no reports to corroborate this function of the amphibian kidney, although $\mathrm{NO}_{3}{ }^{-}$filtration does occur in the mammalian kidney (Kelm 1999). Additional research is needed to determine whether environmental sources of NO metabolites can effectively augment low endogenous levels of NO in amphibians, as is the case with some fishes (Jensen 2009). 


\section{Perspectives}

The general importance of NO availability in stress adaptation of plants has been proposed (Gould et al. 2003), but this tenet warrants consideration for animals as well. Species (or populations) tolerant to hypoxia, notably the ectotherms T. scripta, C. carassius, and C. auratus, and even a diving mammal, Phocoena phocoena, maintain relatively high constitutive levels of plasma $\mathrm{NO}_{2}{ }^{-}$and, thus, NO availability (Fago and Jensen 2015; Jacobsen et al. 2012). Our results indicate that $R$. sylvatica is extraordinary in this regard (Table 3). Moreover, the considerably higher $(P<0.001)$ plasma concentration of $\mathrm{NO}_{2}^{-}$in hibernating Alaskan frogs $(\mathrm{MH}$ group: $6.8 \pm 0.2 \mu \mathrm{mol} \mathrm{l}^{-1} ; n=9$ ) as compared to that of hibernating Ohioan frogs (reference group, hypoxia exposure experiment: $2.6 \pm 0.5 \mu \mathrm{mol}^{-1} ; n=8$ ) appears consistent with their need to endure the exceptionally long and severe subarctic winter. Future research should determine whether the association between hypoxia tolerance and NO availability extends to tolerances of other perturbations, such as dehydration, freezing, and iono-osmotic stress. 


\section{References}

Benhar M (2015) Nitric oxide and the thioredoxin system: a complex interplay in redox regulation Biochim Biophys Acta 1850:2476-2484

Bickler PE, Buck LT (2007) Hypoxia tolerance in reptiles, amphibians, and fishes: Life with variable oxygen availability Annual Review of Physiology 69:145-170

Costanzo JP, Do Amaral MCF, Rosendale AJ, Lee RE (2013) Hibernation physiology, freezing adaptation and extreme freeze tolerance in a northern population of the wood frog $\mathrm{J}$ Exp Biol 216:3461-3473

Costanzo JP, Lee RE (2005) Cryoprotection by urea in a terrestrially-hibernating frog J Exp Biol 208:4079-4089

Costanzo JP, Lee RE (2013) Avoidance and tolerance of freezing in ectothermic vertebrates J Exp Biol 216:1961-1967

Costanzo JP, Lee RE, Lortz PH (1993) Physiological responses of freeze-tolerant and -intolerant frogs: clues to evolution of anuran freeze tolerance Am J Physiol Regul Integr Comp Physiol 264:R721-R725

Costanzo JP, Reynolds AM, do Amaral MCF, Rosendale AJ, Lee RE (2015) Cryoprotectants and Extreme Freeze Tolerance in a Subarctic Population of the Wood Frog PLoS One:1-23

Crane BR, Sudhamsu J, Patel RP (2010) Bacterial nitric oxide synthases Annu Rev Biochem $79: 445-470$

Duranski MR et al. (2005) Cytoprotective effects of nitrite during in vivo ischemia-reperfusion of the heart and liver J Clin Invest 115:1232-1240

Erzurum SC et al. (2007) Higher blood flow and circulating NO products offset high-altitude hypoxia among Tibetans PNAS 104:17593-17598

Fago A, Jensen FB (2015) Hypoxia tolerance, nitric oxide, and nitrite: Lessons from extreme animals Physiology 30:116-126

Filogonio R, Joyce W, Wang T (2017) Nitrergic cardiovascular regulation in the African lungfish, Protopterus aethiopicus Comp Biochem Physiol, A: Mol Integr Physiol 2017:52-56

Forgan LG, Sofele M, McNeill B, Cameron MS, Donald JA (2018) Vasoactivity of nitrite in the illiac artery of the toad Rhinella marina Am J Physiol Regul Integr Comp Physiol 314:R242-R251 
Forstermann U, Sessa WC (2012) Nitric oxide synthases: regulation and function European Heart Journal 33:829-837

González-Domenech CM, Muñoz-Chápuli R (2010) Molecular evolution of nitric oxide sythases in metazoans Comp Biochem Physiol Part D Genomics Proteomics:295-301

González Nicolini MV, Orezzoli AA, Villar MJ (1998) An immunohistochemical study of temperature-related changes in galanin and nitric oxide synthase immunoreactivity in the hypothalamus of the toad Gen Comp Endocrinol 110:175-181

Gould KS, Lamtte O, Klinguer A, Pugin A, Wendehenne D (2003) Nitric oxide production in tobacco leaf cells: a generalized stress response? Plant, Cell and Environment 26:18511862

Guillette LJ, Edwards TM (2005) Is nitrate an ecologically relevant endocrine disruptor in vertebrates? Integr Comp Biol 45:19-27

Guoyao WU, Morris SM (1998) Arginine metabolism: nitric oxide and beyond Biochem J 336:117

Hansen MN, Jensen FB (2010) Nitric oxide metabolites in goldfish under normoxic and hypoxic conditions J Exp Biol 213:3593-3602

Hogg N, Kalyanaraman B (1999) Nitric oxide and lipid peroxidation Biochim Biophys Acta 1411:378-384

Holden CP, Storey KB (1997) Second messenger and cAMP-dependent protein kinase responses to dehydration and anoxia stresses in frogs J Comp Physiol B 167:305-312

Illanes MDV, Storey KB (1993) 6-Phosphofructo-2-kinase and control of cryoprotectant synthesis in freeze tolerant frogs Biochim Biophys Acta 1158:29-32

Jackson DC, Ultsch GR (2010) Physiology of hibernation under the ice by turtles and frogs J Exp Zool A Ecol Genet Physiol 313A:311-327

Jacobsen SB, Hansen MN, Jensen FB, Skovgaard N, Wang T, Fago A (2012) Circulating nitric oxide metabolites and cardiovascular changes in the turtle Trachemys scripta during normoxia, anoxia and reoxygenation J Exp Biol 215:2560-2566

Jensen FB (2009) The role of nitrite in nitric oxide homeostasis: A comparative perspective Biochim Biophys Acta 1787:841-848

Jensen FB, Gerber L, Hansen MN, Madsen SS (2015) Metabolic fates and effects of nitrite in brown trout under normoxic and hypoxic conditions: blood and tissue nitrite metabolism 
and interactions with branchial NOS, $\mathrm{Na}+/ \mathrm{K}+$-ATPase and $h s p 70$ expression J Exp Biol 218:2015-2022

Jensen FB, Hansen MN, Montesanti G, Wang T (2014) Nitric oxide metabolites during anoxia and reoxygenation in the anoxia-tolerant vertebrate Trachemys scripta J Exp Biol 217:423-431

Jobgen WS, Fried SK, Fu WJ, Meininger CJ, Wu G (2006) Regulatory role for the argininenitric oxide pathway in metabolism of energy substrates Journal of Nutritional Biochemistry 17:571-588

Kelm M (1999) Nitric oxide metabolism and breakdown Biochim Biophys Acta 1411:273-289

Kirton MP (1974) Fall movements and hibernation of the wood frog, Rana sylvatica, in Interior Alaska. M.S. Thesis, University of Alaska

Kleinbongard P et al. (2003) Plasma nitrite reflects constitutive nitric oxide synthase activity in mammals Free Radical Biol Med 35:790-796

Larson DJ, Middle L, Vu H, Zhang W, Serianni AS, Duman J, Barnes BM (2014) Wood frog adaptations to overwintering in Alaska: new limits to freeze tolerance J Exp Biol 217:2193-2200

Layne JR (1991) External ice triggers freezing in freeze-tolerant frogs at temperatures above their supercooling point J Herpetol 25:129-130

López-Barneo J, Nurse CA, Nilsson GE, Buck LT, Gassmann M, Bogdanova AY (2010) First aid kit for hypoxic survival: Sensors and Strategies Physiol Biochem Zool 83:753-763

Lundberg JO, Weitzberg E, Gladwin MT (2008) The nitrate-nitrite-nitric oxide pathway in physiology and therapeutics Nature Reviews Drug Discovery 7:156-167

McNeill B, Perry SF (2006) The interactive effects of hypoxia and nitric oxide on catecholamine secretion in rainbow trout (Oncorhynchus mykiss) J Exp Biol 209:4214-4223

Mornagui B, Grissa A, Duvareille M, Gharib C, Kamoun A, El-Fazaa S, Gharbi N (2006) Vasopressin and nitric oxide synthesis after three days of water or food deprivation Acta Biol Hung 57:1-11

Olson KR, Donald JA, Dombkowski RA, Perry SF (2012) Evolutionary and comparative aspects of nitric oxide, carbon monoxide and hydrogen sulfide Respir Physiol Neurobiol $184: 117-129$ 
Puyabert J, Baudouin E (2014) New clues for a cold case: nitric oxide response to low temperature Plant, Cell and Environment 37:2623-2630

Revsbech IG et al. (2014) Hydrogen sulfide and nitric oxide metabolites in the blood of freeranging brown bears and their potential roles in hibernation Free Radical Biol Med $73: 349-357$

Rosendale AJ, Lee RE, Costanzo JP (2014) Effect of physiological stress on expression of glucose transporter 2 in liver of the wood frog, Rana sylvatica J Exp Zool 321A:566-576

Rouse JD, Bishop CA, Struger J (1999) Nitrogen pollution: An assessment of its threat to amphibian survival Environ Health Perspect 107:799-803

Sandvik GK, Nilsson GE, Jensen FB (2012) Dramatic increase of nitrite levels in hearts of anoxia-exposed crucian carp supporting a role in cardioprotection Am J Physiol Regul Integr Comp Physiol 302:R468-477

Soegaard LB, Hansen MN, van Elk C, Brahm J, Jensen FB (2012) Respiratory properties of blood in the harbor porpoise, Phocoena phocoena J Exp Biol 215:1938-1943

Storey KB, Storey JM (2017) Molecular physiology of freeze tolerance in vertebrates Physiol Rev 97:623-665

Swenson KE, Eveland RL, Gladwin MT, Swenson ER (2005) Nitric Oxide (NO) in Normal and Hypoxic Vascular Regulation of the Spiny Dogfish, Squalus acanthias J Exp Zool 303 A:154-160

Umbrello M, Dyson A, Feelisch M, Singer M (2013) The Key Role of Nitric Oxide in Hypoxia: Hypoxic Vasodilation and Energy Supply-Demand Matching Antioxid Redox Signal 00:1-21 doi:10.1089/ars.2012.4979

Webb A, Bond R, McLean P, Uppal R, Benjamin N, Ahluwalla A (2004) Reduction of nitrite to nitric oxide during ischemia protects against myocardial ischemia-reperfusion damage PNAS 101:13683-13688

Welker TL, Lim C, Mediha Y-A, Shelby R, Klesius PH (2007) Immune response and resistance to stress and Edwardsiella ictaluri challenge in Channel catfish, Ictalurus punctatus, fed diets containing commercial whole-cell yeast or yeast subcomponents J World Aquacult Soc 38:24-35 
Xu Q, Hu Y, Kleindienst R, Wick G (1997) Nitric oxide induces heat shock protein 70 expression in vascular smooth muscle cells via activation of heat shock factor $1 \mathrm{~J}$ Clin Invest 100:1089-1097 
Figures

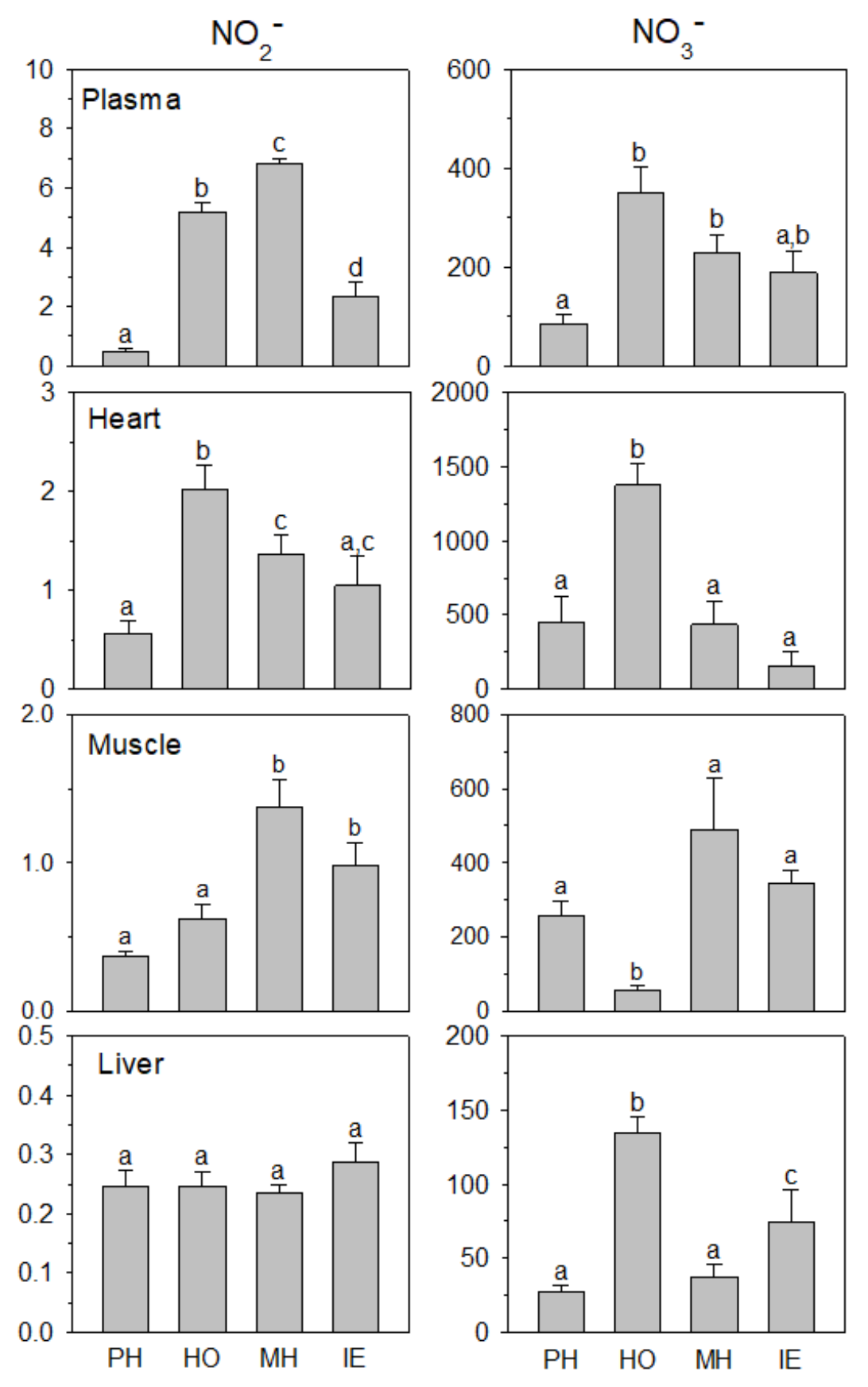




\section{Tables}

Table 1 Concentrations of $\mathrm{NO}$ metabolites $\left(\mathrm{NO}_{2}{ }^{-}\right.$and $\left.\mathrm{NO}_{3}{ }^{-}\right)$in blood plasma and organs of Ohioan wood frogs sampled after hypoxia exposure or hypoxia exposure followed by $4 \mathrm{~h}$ of normoxia exposure (recovery)

\begin{tabular}{|c|c|c|c|c|c|c|c|c|}
\hline & \multicolumn{4}{|c|}{$\mathrm{NO}_{2}^{-}$} & \multicolumn{4}{|c|}{$\mathrm{NO}_{3}^{-}$} \\
\hline & & Hypoxia- & Hypoxia- & & & Hypoxia- & Hypoxia- & \\
\hline & Reference & Exposure & Recovery & $P$ & Reference & Exposure & Recovery & $P$ \\
\hline Plasma & $2.6 \pm 0.5^{\mathrm{a}}$ & $6.3 \pm 0.7^{b}$ & $3.2 \pm 0.4^{\mathrm{a}}$ & $<0.001$ & $113 \pm 23^{a}$ & $460 \pm 103^{b}$ & $192 \pm 38^{\mathrm{a}}$ & 0.004 \\
\hline Heart & $0.8 \pm 0.1^{\mathrm{a}}$ & $2.2 \pm 0.4^{\mathrm{b}}$ & $2.5 \pm 0.6^{\mathrm{b}}$ & 0.028 & $1,576 \pm 428^{a}$ & $2,418 \pm 669^{a}$ & $3,348 \pm 808^{a}$ & 0.095 \\
\hline Muscle & $1.1 \pm 0.2^{\mathrm{a}}$ & $1.8 \pm 0.3^{\mathrm{a}}$ & $1.3 \pm 0.2^{\mathrm{a}}$ & 0.209 & $769 \pm 172^{\mathrm{a}}$ & $940 \pm 228^{a}$ & $1,386 \pm 365^{a}$ & 0.268 \\
\hline Liver & $1.3 \pm 0.2^{\mathrm{a}}$ & $1.6 \pm 0.1^{\mathrm{a}}$ & $2.3 \pm 0.2^{\mathrm{b}}$ & 0.003 & $406 \pm 100^{\mathrm{a}}$ & $1,665 \pm 374^{\mathrm{b}}$ & $1,394 \pm 304^{b}$ & 0.012 \\
\hline
\end{tabular}

Units are $\mu \mathrm{mol} \mathrm{l}^{-1}$ (plasma), $\mathrm{nmol} \mathrm{g}^{-1}$ fresh tissue (heart, muscle), or nmol g-1 dry tissue (liver)

Within each horizontal block, means ( \pm SEM, $n=7-8)$ assigned distinct superscripted letters were statistically distinguishable $(P<$ 0.05) 
Table 2 Concentrations of $\mathrm{NO}$ metabolites $\left(\mathrm{NO}_{2}{ }^{-}\right.$and $\left.\mathrm{NO}_{3}{ }^{-}\right)$in blood plasma and organs of Ohioan wood frogs sampled after being subjected to a survivable freeze/thaw bout

\begin{tabular}{|c|c|c|c|c|c|c|}
\hline & \multicolumn{3}{|c|}{$\mathrm{NO}_{2}^{-}$} & \multicolumn{3}{|c|}{$\mathrm{NO}_{3}^{-}$} \\
\hline & Reference & Freeze/Thaw & $P$ & Reference & Freeze/Thaw & $P$ \\
\hline Plasma & $2.6 \pm 0.5$ & $1.1 \pm 0.3$ & 0.016 & $113 \pm 23$ & $209 \pm 45$ & 0.079 \\
\hline Heart & $0.8 \pm 0.1$ & $1.5 \pm 0.5$ & 0.303 & $1,576 \pm 428$ & $1,664 \pm 353$ & 0.880 \\
\hline Muscle & $1.1 \pm 0.2$ & $1.1 \pm 0.2$ & 0.849 & $769 \pm 172$ & $1,634 \pm 394$ & 0.167 \\
\hline Liver & $1.3 \pm 0.2$ & $2.1 \pm 0.2$ & 0.022 & $406 \pm 100$ & $1,551 \pm 411$ & 0.021 \\
\hline
\end{tabular}

Units are $\mu \mathrm{mol} \mathrm{l}^{-1}$ (plasma), nmol g ${ }^{-1}$ fresh tissue (heart, muscle), or nmol g${ }^{-1}$ dry tissue (liver) Means within each horizontal block ( \pm SEM, $n=7-8)$ were statistically distinguishable at $P<$ 0.05 
Table 3 Concentrations of $\mathrm{NO}_{2}^{-}$in the blood plasma of some vertebrates

\begin{tabular}{|c|c|c|}
\hline Taxon & $\mathrm{NO}_{2}^{-}\left(\mu \mathrm{mol} \mathrm{l}^{-1}\right)$ & Reference \\
\hline \multicolumn{3}{|l|}{ Chondrichthyes } \\
\hline Spiny dogfish (Squalus acanthias) & 4.5 & Swenson et al. 2005 \\
\hline \multicolumn{3}{|l|}{ Osteichthyes } \\
\hline Crucian carp (Carassius carassius) & 1.8 & Sandvik et al. 2012 \\
\hline Goldfish (Carassius auratus) & 0.8 & Hansen and Jensen 2010 \\
\hline Channel catfish (Ictalurus punctatus) & 0.4 & Welker et al. 2007 \\
\hline Brown trout (Salmo trutta) & 0.3 & Jensen et al. 2015 \\
\hline European flounder (Platichthys flesus) & 0.3 & Jensen 2009 \\
\hline Eelpout (Zoarces viviparus) & 0.2 & Jensen 2009 \\
\hline \multicolumn{3}{|l|}{ Amphibia } \\
\hline Cane toad (Rhinella marina) & $0.9^{*}$ & Forgan et al. 2018 \\
\hline \multicolumn{3}{|l|}{ Wood frog (Rana sylvatica) } \\
\hline temperate region (Ohio) & 2.6 & Present study \\
\hline subarctic (Alaska) & 6.8 & Present study \\
\hline \multicolumn{3}{|l|}{ Reptilia } \\
\hline Red-eared slider (Trachemys scripta & 0.6 & Jensen et al. 2014 \\
\hline elegans) & 2.9 & Jacobsen et al. 2012 \\
\hline \multicolumn{3}{|l|}{ Mammalia } \\
\hline \multirow[t]{2}{*}{ Rabbit (Oryctolagus cuniculus) } & 0.4 & Jensen 2009 \\
\hline & 0.5 & Kleinbongard et al. 2003 \\
\hline Rat (Rattus norvegicus) & 0.2 & Kleinbongard et al. 2003 \\
\hline Human (Homo sapiens) & 0.3 & Kleinbongard et al. 2003 \\
\hline High elevation $(4,200 \mathrm{~m})$ & $4.8(\overbrace{}^{\Uparrow}) 11.0($ (ㅇ) & Erzurum et al. 2007 \\
\hline Monkey (Maccaca mulatta) & 0.4 & Kleinbongard et al. 2003 \\
\hline Brown bear (Ursus arctos) & 0.1 & Revsbech et al. 2014 \\
\hline Dog (Canis lupus familiaris) & 0.3 & Kleinbongard et al. 2003 \\
\hline Harbor porpoise (Phocoena phocoena) & 3.3 & Soegaard et al. 2012 \\
\hline
\end{tabular}

